\title{
Incidence and risk factors for incisional hernia after abdominal aortic aneurysm and aortic occlusive disease surgery
}

\author{
Abdominal aort anevrizması ve aorto-oklüziv hastalık cerrahisi sonrası gelişen \\ insizyonel herni insidansı ve risk faktörleri

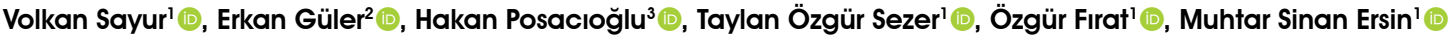 \\ Institution where the research was done: \\ Ege University Faculty of Medicine, Izmir, Turkey \\ Author Affiliations: \\ 'Department of General Surgery, Ege University Faculty of Medicine, Izmir, Turkey \\ ${ }^{2}$ Department of General Surgery, Mersin University Faculty of Medicine, Mersin, Turkey \\ ${ }^{3}$ Department of Cardiovascular Surgery, Ege University Faculty of Medicine, Izmir, Turkey
}

\begin{abstract}
Background: This study aims to investigate incisional hernia incidence and risk factors after abdominal aortic aneurysm and aortic occlusive disease surgery via a midline laparotomy.

Methods: A total of 110 patients (66 males, 44 females; mean age: $69.3 \pm 8.8$ years; range, 36 to 88 years) who underwent open elective surgery for aortoiliac occlusive diseases or abdominal aortic aneurysm between January 2005 and December 2016 were retrospectively analyzed. Both patient groups were compared in terms of surgical procedures, sex, age, American Society of Anesthesiologists score (1-3), body mass index $\left(<25 v s . \geq 25 \mathrm{~kg} / \mathrm{m}^{2}\right)$, smoking (non-smoker $<1$ pack/day, smoking $\geq 1$ pack/day), and time to incisional hernia development.

Results: Incisional hernia occurred in $14.3 \%$ of the patients operated for aortoiliac occlusive disease and in $17.6 \%$ of the patients operated for abdominal aortic aneurysm $(\mathrm{p}=0.643)$. Incisional hernia was seen in three $(5.7 \%)$ of 53 patients with a body mass index of $<25 \mathrm{~kg} / \mathrm{m}^{2}$ and was in $15(26.3 \%)$ of 57 patients with a body mass index of $\geq 25 \mathrm{~kg} / \mathrm{m}^{2}(\mathrm{p}=0.03)$.

Conclusion: High body mass index is a risk factor for incisional hernia in patients undergoing aortic reconstructive surgery.
\end{abstract}

Keywords: Abdominal aortic aneurysm, body mass index, incisional hernia.

\section{$\ddot{O} Z$}

Amaç: Bu çalışmada orta hat laparotomisi ile abdominal aort anevrizması ve aorto-oklüziv hastalık cerrahisi sonrasında insizyonel herni insidansı ve risk faktörleri araştırıldı.

Çalışma planı: Ocak 2005 - Aralık 2016 tarihleri arasında aortoiliyak oklüziv hastalıklar veya abdominal aort anevrizması nedeniyle açık elektif cerrahi uygulanan toplam 110 hasta (66 erkek, 44 kadın; ort. yaş: 69.3 \pm 8.8 yıl; dağılım, 36-86 yıl) retrospektif olarak incelendi. İki hasta grubu cerrahi işlemler, cinsiyet, yaş, Amerikan Anesteziyoloji Derneği skoru (1-3), vücut kütle indeksi ( $<25 \mathrm{ve} \geq 25 \mathrm{~kg} / \mathrm{m} 2$ ), sigara içiciliği (sigara içmeyen $<1$ paket/gün, sigara $\geq 1$ paket/gün) ve insizyonel herni gelişme süresi açısından karşılaştırıldı.

Bulgular: Aortoiliyak oklüziv hastalık nedeniyle ameliyat edilen hastaların \%14.3'ünde ve abdominal aort anevrizması nedeniyle ameliyat edilen hastaların \%17.6'sında insizyonel herni gelişti $(\mathrm{p}=0.643)$. Vücut kütle indeksi $<25 \mathrm{~kg} / \mathrm{m}^{2}$ olan 53 hastanın üçünde (\%5.7) ve vücut kütle indeksi $\geq 25 \mathrm{~kg} / \mathrm{m}^{2}$ olan 57 hastanın 15'inde (\%26.3) insizyonel herni izlendi ( $\mathrm{p}=0.03)$.

Sonuç: Yüksek vücut kütle indeksi, aortik rekonstrüktif cerrahi geçiren hastalarda insizyonel herni gelişimi için bir risk faktörüdür.

Anahtar sözcükler: Abdominal aort anevrizması, vücut kütle indeksi, insizyonel herni.

Received: June 17, 2021 Accepted: October 14, 2021 Published online: October 20, 2021

Correspondence: Erkan Güler, MD. Mersin Üniversitesi Tıp Fakültesi, Genel Cerrahi Anabilim Dalı, 33343 Yenişehir, Mersin, Türkiye. Tel: +90 535 - 0344939 e-mail: drerkangler@gmail.com 
Incisional hernia is a well-known complication of abdominal surgery, occurring in 2 to $37 \%$ of patients. ${ }^{[1-6]}$ Many previous studies have shown that the prevalence and incidence of incisional hernia are higher in patients having an abdominal aortic aneurysm (AAA) operation than patients undergoing aortoiliac occlusive disease (AOD).$^{[1-3]}$ One of the hypotheses regarding this condition is that the pathogenesis of both aortic aneurysm and incisional hernia development may be related to connective tissue metabolism disorder. This pathogenesis has not been elucidated, yet. ${ }^{[6,7]}$ In some small-scale studies, there is no significant difference between AAA and AOD in terms of incisional hernia development. ${ }^{[4,5]}$

Risk factors for incisional hernia in several studies are male sex, smoking, postoperative wound infections, abdominal closure techniques, obesity, advanced age, postoperative pulmonary complications, abdominal distension, emergency operation, previous operations, steroid use, pregnancy, postoperative chemotherapy, malnutrition, acid, and peritoneal dialysis. ${ }^{[5-7]}$

In the present study, we aimed to investigate differences between AAA and AOD groups for incisional hernia development after abdominal reconstructive surgery and risk factors for incisional hernia in both groups.

\section{PATIENTS AND METHODS}

This single-center, retrospective study was conducted at Ege University Faculty of Medicine University, Faculty of Medicine, Department of Cardiovascular Surgery between January 2005 and December 2016. A total of 287 patients older than 18 years old who underwent elective open abdominal surgery due to AOD or AAA were included. Data including age, sex, American Society of Anesthesiologists (ASA) score, body mass index (BMI), smoking status, and type of surgery were retrieved from the hospital database. Patients were excluded, if they had previous abdominal surgery, emergency surgery, or a retroperitoneal approach and a transverse incision. Open elective surgeries that performed transabdominally with a midline incision for AAA and AOD repair were included. Ninety-four of these patients were excluded due to previous abdominal surgery and emergency surgery. Eighty-three patients were excluded from the study due to a retroperitoneal approach or a

Table 1. Data of the patients

\begin{tabular}{|c|c|c|c|c|c|c|}
\hline & \multicolumn{2}{|c|}{$\begin{array}{l}\text { Aortoiliac occlusive } \\
\text { disease }(n=42)\end{array}$} & \multicolumn{2}{|c|}{$\begin{array}{l}\text { Abdominal aortic } \\
\text { aneurysm }(n=68)\end{array}$} & \multirow[b]{2}{*}{$p$} & \multirow[b]{2}{*}{$p^{*}$} \\
\hline & $\mathrm{n}$ & Mean \pm SD & $\mathrm{n}$ & Mean \pm SD & & \\
\hline Age (year) & & $70.1 \pm 10.1$ & & $68.7 \pm 9.6$ & 0.416 & \\
\hline Sex & & & & & 0.749 & \\
\hline Male & 26 & & 40 & & & \\
\hline Female & 16 & & 28 & & & \\
\hline ASA score & & & & & & 0.091 \\
\hline 1 & 12 & & 16 & & 0.56 & \\
\hline 2 & 20 & & 22 & & 0.11 & \\
\hline 3 & 10 & & 30 & & 0.03 & \\
\hline $\operatorname{BMI}\left(<25 \mathrm{~kg} / \mathrm{m}^{2}\right)$ & 17 & & 40 & & 0.061 & \\
\hline BMI $\left(\geq 25 \mathrm{~kg} / \mathrm{m}^{2}\right)$ & 25 & & 28 & & & \\
\hline Smoking & & & & & & 0.928 \\
\hline++ & 20 & & 30 & & 0.72 & \\
\hline+ & 12 & & 20 & & 0.93 & \\
\hline- & 10 & & 18 & & 0.76 & \\
\hline Types of surgical procedures & & & & & & 0.895 \\
\hline Aortobifemoral & 20 & & 38 & & 0.39 & \\
\hline Aortofemoral & 14 & & 18 & & 0.44 & \\
\hline Aortobiiliac & 5 & & 6 & & 0.6 & \\
\hline Aortoiliac & 2 & & 4 & & 0.8 & \\
\hline Aortoiliac and femoral & 1 & & 2 & & 0.86 & \\
\hline
\end{tabular}

SD: Standard deviation; ASA: American Society of Anesthesiologists; BMI: Body mass index; * P-value indicates whether there is a significant difference between the groups in three or more groups; ++: $\geq 1$ Pack/day; +: $<1$ Pack/day -: Non-smoker. 
transverse incision and missing data. Finally, a total of 110 patients (66 males, 44 females; mean age: $69.3 \pm 8.8$ years; range, 36 to 88 years) who met the inclusion criteria were included in the study. The patients were divided into two groups: those operated for AOD and those operated for AAA. Both groups were compared in terms of surgical technique (bypass procedures: aorto-aortic, aortobifemoral, aortofemoral, aortobiiliac, aortoiliac, aortoiliac and femoral), sex (female-male), age, ASA score (ASA 1-3), BMI <25 $v s . \geq 25 \mathrm{~kg} / \mathrm{m}^{2}$ ), smoking (no smoker, smoking $<1$ pack/ day, smoking $\geq 1$ pack/day). The follow-up period was from the vascular operation to the incisional hernia development. A written informed consent was obtained from each patient. The study protocol was approved by the Ege University Faculty of Medicine Ethics Committee (No: 02-11-2018-E.314087-4792). The study was conducted in accordance with the principles of the Declaration of Helsinki.

\section{Statistical analysis}

Statistical analysis was performed using the IBM SPSS version 25.0 software (IBM Corp., Armonk, NY, USA). Descriptive data were expressed in mean \pm standard (SD), median (min-max) or number and frequency. Categorical variables were analyzed using the chi-square test or Mann-Whitney U test. Continuous variables were analyzed using the Student t-test. Univariate analysis including sex, age, ASA score, BMI, smoking, and types of surgical procedure was performed to evaluate the risk of incisional hernia development. A $p$ value of $<0.05$ was considered statistically significant.

\section{RESULTS}

Of a total of 110 patients, $42(38.16 \%)$ were operated with the diagnosis of AOD, while 68 (61.81\%) were operated with the diagnosis of AAA.

Table 2. Variables associated with incisional hernia development

\begin{tabular}{|c|c|c|c|c|c|c|}
\hline & \multicolumn{2}{|c|}{$\begin{array}{l}\text { Hernia group } \\
\quad(\mathrm{n}=18)\end{array}$} & \multicolumn{2}{|c|}{$\begin{array}{l}\text { No hernia group } \\
\quad(\mathrm{n}=92)\end{array}$} & \multirow[b]{2}{*}{$p$} & \multirow[b]{2}{*}{$p^{*}$} \\
\hline & $\mathrm{n}$ & Mean \pm SD & $\mathrm{n}$ & Mean \pm SD & & \\
\hline Age (year) & & $69.8 \pm 10.2$ & & $69.2 \pm 8.6$ & 0.77 & \\
\hline Sex & & & & & 0.92 & \\
\hline Male & 11 & & 55 & & & \\
\hline Female & 7 & & 37 & & & \\
\hline ASA score & & & & & & 0.52 \\
\hline 1 & 4 & & 24 & & 0.73 & \\
\hline 2 & 9 & & 33 & & 0.26 & \\
\hline 3 & 5 & & 35 & & 0.41 & \\
\hline $\operatorname{BMI}\left(<25 \mathrm{~kg} / \mathrm{m}^{2}\right)$ & 15 & & 42 & & 0.003 & \\
\hline BMI $\left(\geq 25 \mathrm{~kg} / \mathrm{m}^{2}\right)$ & 3 & & 50 & & & \\
\hline Smoking & & & & & & 0.41 \\
\hline++ & 9 & & 41 & 0.67 & & \\
\hline+ & 3 & & 29 & 0.2 & & \\
\hline- & 6 & & 22 & 0.4 & & \\
\hline Types of surgery & & & & 0.64 & & \\
\hline AOD & 6 & & 36 & & & \\
\hline AAA & 12 & & 56 & & & \\
\hline Types of surgical procedures & & & & & & 0.95 \\
\hline Aortobifemoral & 9 & & 49 & & 0.8 & \\
\hline Aortofemoral & 5 & & 27 & & 0.89 & \\
\hline Aortobiiliac & 2 & & 9 & & 0.86 & \\
\hline Aortoiliac & 1 & & 5 & & 0.98 & \\
\hline Aortoiliac and femoral & 1 & & 2 & & 0.42 & \\
\hline
\end{tabular}

SD: Standard deviation; ASA: American Society of Anesthesiologists; BMI: Body mass index; AOD: Aortoiliac occlusive disease; AAA :Abdominal aortic aneurysm; * P-value indicates whether there is a significant difference between the groups in three or more groups; ++: >1 Pack/day; +: <1 Pack/day -: Non-smoker 
There was no statistically significant difference between the two groups regarding age, sex, ASA 1, ASA 2, BMI, smoking, and types of surgical procedures $(p>0.05)$. However, the number of patients with ASA 3 was significantly higher in the AAA group than in the AOD group $(\mathrm{p}=0.03)$. Table 1 summarizes the demographic and baseline data of the patients.

Variables associated with incisional hernia development are listed in Table 2 . A BMI of $\geq 25 \mathrm{~kg} / \mathrm{m}^{2}$ was a risk factor for incisional hernia development $(p=0.003)$, whereas no significant difference was found between the patients regarding to age, sex, ASA score, smoking, types of surgery, and types of surgical procedures (Table 2).

The incisional hernia occurred in six (14.3\%) patients in the AOD group (five of whom had a BMI of $\left.\geq 25 \mathrm{~kg} / \mathrm{m}^{2}\right)$ and $12(17.6 \%)$ patients in the AAA group (10 of whom had a BMI of $\geq 25$ ) (Table 2). Although the incisional hernia development rate was higher in the AAA group, it did not reach statistical significance $(\mathrm{p}=0.643)$.

Incisional hernia occurred in 18 patients (mean age: $69.8 \pm 10.2$ years). The mean age of 92 patients without an incisional hernia was $69.2 \pm 8.6$ years $(p=0.767)$. The mean time from primary surgery to the incisional hernia repair was $22.7 \pm 9.1$ months in the AOD group and $20.8 \pm 10.0$ months in the AAA group, indicating no statistically significant difference between the two groups $(\mathrm{p}=0.713)$.

In the AAA group, aortobifemoral bypass was performed in $38(55.9 \%)$, aortofemoral bypass in 18 $(26.5 \%)$, aortobiiliac bypass in six $(8.8 \%)$, aortoiliac bypass in four (5.9\%), and aortoiliac and femoral bypass in two (2.9\%) patients. There was no statistically significant difference between the two groups according to types of surgical procedures $(\mathrm{p}=0.895)$. In addition, there was no significant correlation between the types of aortic surgical procedures and incisional hernia development $(\mathrm{p}=0.951)$ (Table 2$)$.

\section{DISCUSSION}

The main findings of the current study are that there was no statistically significant difference between the AAA and AOD groups in terms of incisional hernia development, and high BMI $\left(\geq 25 \mathrm{~kg} / \mathrm{m}^{2}\right)$ was found to be an independent risk factor for incisional hernia development in patients undergoing elective aortic reconstruction surgery.

The relationship between incisional hernia and AAA has been frequently questioned in the literature.
A total of 17 articles were reviewed in a systematic review and meta-analysis published earlier this year, and 107,578 patients were eligible for metaanalysis. ${ }^{[7]}$ In four of these studies investigating AAA incidence, AAA was more common in hernia patients than patients without hernia. Among the 13 studies comparing patients with AAA and no AAA, hernia incidence was higher in AAA patients than in those without. ${ }^{[7]}$ However, some studies did not indicate an increased risk in the AAA group than other abdominal surgery groups. These studies showed that the abdominal wall closure technique played a more critical role. ${ }^{[5,8]}$ However, these studies are very few with relatively small sample sizes.

In the literature, there is a limited number of studies comparing the groups in terms of incisional hernia development between AAA and AOD, and it has been reported that the incisional hernia rate is often higher in the AAA group. ${ }^{[2,4]}$ A large multi-center study by Henriksen et al. ${ }^{[2]}$ evaluated 2,597 patients, including 838 and 1,759 who underwent open elective surgery for an AOD and AAA, respectively. According to this study, high BMI and AAA repair were independent risk factors for incisional hernia development in patients undergoing aortic reconstructive surgery. The ASA scores, sex, age, and surgical site infection were also investigated; however, none of them were found to be statistically significant. In this study, the median time from primary surgery to the incisional hernia repair was 14.8 months in AOD patients and 16.1 months in AAA patients $(\mathrm{p}=0.355)$. In our study, the median time from primary surgery to the incisional hernia development was 22.7 \pm 9.1 months in the AOD group and $20.8 \pm 10.0$ months in the AAA group $(\mathrm{p}=0.713)$, consistent with the literature data.

In previous studies, the incisional hernia development rate ranged from 11 to $42 \%$ in the AAA group and 2 to $12 \%$ in the AOD group. ${ }^{[9,10]}$ This rate was $16.7 \%$ in patients with AAA and $9.9 \%$ in the AOD group in subsequent studies. ${ }^{[2,4,11]}$ In our study, the cumulative incidence of total incisional hernia was $16.4 \%$. It was $17.6 \%$ in the AAA group and $14.3 \%$ in the AOD group $(\mathrm{p}=0.643)$. The incisional hernia was more common in the AAA group than the AOD group. However, there was no statistically significant difference between the two groups $(\mathrm{p}=0.643)$. A few studies reported similar results to ours. ${ }^{[4,5]}$ A similar incisional hernia incidence was reported in both groups in a study of 1,065 patients by Gruppo et al. ${ }^{[4]}$ (412 with AAA and 653 with AOD) $(\mathrm{p}=0.061)$. This study emphasized that the abdominal closure technique, suture length-to-wound length ratio (SL:WL) was an independent risk factor for the 
development of incisional hernia, suggesting that an SL:WL ratio of at least 4:1 should be used.

Several studies have shown that morbid obesity is directly related to incisional hernia. ${ }^{[12,13]}$ In addition, the size and type of incisional hernia are different in these patient groups, and the risk of recurrence is higher after repair. ${ }^{[13]}$ The incision type is also associated with the incisional hernia incidence in patients undergoing abdominal open vascular surgery. ${ }^{[14]}$ However, some studies have reported no significant difference between the incision type and hernia. ${ }^{[6,15]}$ According to a recent systematic review, five studies compared transverse with midline incisions in a total of 3,399 patients $(2,098$ with transverse and 1,301 midline incisions). ${ }^{[6]}$ There was a trend toward a benefit of transverse incisions, but the results were not significant $(\mathrm{p}=0.08)$. This variable could not be compared in our study, since all patients were operated with a midline incision.

Furthermore, patients operated for an AAA are usually older than patients operated for other aortoiliac vascular diseases..$^{[4,6,9]}$ In our study, the mean age was $70.1 \pm 10.1$ in the AOD group and $68.7 \pm 9.6$ in the AAA group, indicating no statistically significant difference. Some authors have noted a risk factor for male sex incisional hernia. ${ }^{[16,17]}$ However, in the following period, male sex was not found to be a risk factor..$^{[2,6,7]}$ In our study, there was no significant difference in the incisional hernia development rates between two sexes. Most of the patients operated for AAA and AOD are active smokers or those with a high smoking history. In some studies, smoking was reported as a risk factor. ${ }^{[16,17]}$ In other studies, smoking was not a statistically significant risk factor. ${ }^{[2,7]}$ In our study, smoking was not a risk factor, either $(\mathrm{p}=0.414)$. Also, the ASA score was not a risk factor $(\mathrm{p}=0.519)$.

The fascia closure technique has been reported as a significant risk factor for incisional hernia development. Two studies compared the rates of hernia development according to the SL:WL of less or more than $4: 1 .^{[4,18]}$ A total of 483 patients were included (217 with a ratio less than, and 266 with a ratio greater than 4:1). According to these studies, the SL:WL strongly affected incisional hernia development. There was a significant difference in the hernia risk ratio between the two groups $(p<00.1) .^{[4,18]}$ Our study does not compare these closure techniques, which can be deemed as a limitation.

In a study of 17,594 patients $(9,314$ with AAA and 8,280 with AOD) by Altieri et al., ${ }^{[19]}$ after controlling for all other factors, patients undergoing
AAA repair were more likely to undergo ventral hernia repair (7.93\% with AAA and 5.8\% with AOD). The authors concluded that prophylactic use of mesh might be considered in this patient population for future procedures due to their significant comorbidity. Prophylactic mesh reinforcement may be considered for patients in some high-risk groups including patients undergoing undergo bariatric surgery, a stoma, or high-risk gastrointestinal surgery. In a recent meta-analysis performed by Indrakusuma et al., ${ }^{[20]}$ four studies were included. According to this meta-analysis, mesh augmentation significantly reduced the risk of developing incisional hernia.

Collagen tissue defect, common gene mutation, or clear biological indicator have not yet been fully elucidated in the formation of AAA and abdominal wall hernias. In recent studies, the aortic aneurysm pathogen is not based on collagen defect as previously thought; more recent experimental studies have focused on inflammation as the main cause of aortic wall weakening during the process of aneurysm development. ${ }^{[21,22]}$ It is well known that repairs with endovascular methods (i.e., endovascular aneurysm repair and thoracic endovascular aortic repair) are used more frequently in recent years. Patients treated with these methods were not included in our study. In addition, endovascular techniques are performed for particularly high-risk patients.

This study has some limitations. First, this study has a single-center, retrospective, non-randomized design with a relatively small sample size. Further prospective, randomized studies would provide more accurate results on this subject. In addition, the suture type, suturing method, and length of incision were not evaluated. Furthermore, the rate of postoperative wound dehiscence was unknown. Finally, the presence of connective tissue disorders and immunosuppressive medicine could help to evaluate possible risk factors for incisional hernia repair.

In conclusion, high body mass index is a risk factor for incisional hernia development in patients undergoing elective aortic reconstruction surgery. In our study, although the incisional hernia incidence was higher in the AAA group, it did not reach statistical significance between the AAA and AOD groups. Based on these findings, there is a trend toward a tendency of AAA for incisional hernia development in patients undergoing open elective aortic reconstructive surgery; however, further clinical studies are required to evaluate incisional hernia risk and reduce the incidence. 


\section{Declaration of conflicting interests}

The authors declared no conflicts of interest with respect to the authorship and/or publication of this article.

\section{Funding}

The authors received no financial support for the research and/or authorship of this article.

\section{REFERENCES}

1. Pannu R, McPhail IR. Prevalence of abdominal wall hernia in participants with abdominal aortic aneurysm versus peripheral arterial disease--a population-based study. Angiology 2012;63:146-9.

2. Henriksen NA, Helgstrand F, Vogt KC, Jorgensen LN, Bisgaard T; Danish Hernia Database; Danish Vascular Registry. Risk factors for incisional hernia repair after aortic reconstructive surgery in a nationwide study. J Vasc Surg 2013;57:1524-30.

3. Raffetto JD, Cheung Y, Fisher JB, Cantelmo NL, Watkins MT, Lamorte WW, et al. Incision and abdominal wall hernias in patients with aneurysm or occlusive aortic disease. J Vasc Surg 2003;37:1150-4.

4. Gruppo M, Mazzalai F, Lorenzetti R, Piatto G, Toniato A, Ballotta E. Midline abdominal wall incisional hernia after aortic reconstructive surgery: A prospective study. Surgery 2012;151:882-8.

5. Johnson B, Sharp R, Thursby P. Incisional hernias: Incidence following abdominal aortic aneurysm repair. J Cardiovasc Surg (Torino) 1995;36:487-90.

6. Nicolajsen CW, Eldrup N. Abdominal closure and the risk of incisional hernia in aneurysm surgery - a systematic review and Meta-analysis. Eur J Vasc Endovasc Surg 2020;59:227-36.

7. Kontogeorgi E, Sagris M, Kokkinidis DG, Hasemaki N, Tsakotos G, Tsapralis D, et al. Abdominal aortic aneurysms and abdominal wall hernias - a systematic review and metaanalysis. Vasa 2021;50:270-9.

8. Wiegering A, Liebetrau D, Menzel S, Bühler C, Kellersmann $\mathrm{R}$, Dietz UA. The incidence of incisional hernia after aortic aneurysm is not higher than after benign colorectal interventions: A retrospective control-matched cohort study. Gefasschirurgie 2018;23(Suppl 1):23-31.

9. Hall KA, Peters B, Smyth SH, Warneke JA, Rappaport WD, Putnam CW, et al. Abdominal wall hernias in patients with abdominal aortic aneurysmal versus aortoiliac occlusive disease. Am J Surg 1995;170:572-5.

10. Holland AJ, Castleden WM, Norman PE, Stacey MC. Incisional hernias are more common in aneurysmal arterial disease. Eur J Vasc Endovasc Surg 1996;12:196-200.

11. Liapis CD, Dimitroulis DA, Kakisis JD, Nikolaou AN, Skandalakis P, Daskalopoulos M, et al. Incidence of incisional hernias in patients operated on for aneurysm or occlusive disease. Am Surg 2004;70:550-2.

12. Sugerman HJ, Kellum JM Jr, Reines HD, DeMaria EJ, Newsome HH, Lowry JW. Greater risk of incisional hernia with morbidly obese than steroid-dependent patients and low recurrence with prefascial polypropylene mesh. Am J Surg 1996;171:80-4.

13. Sauerland S, Korenkov M, Kleinen T, Arndt M, Paul A. Obesity is a risk factor for recurrence after incisional hernia repair. Hernia 2004;8:42-6.

14. Fassiadis N, Roidl M, Hennig M, South LM, Andrews SM. Randomized clinical trial of vertical or transverse laparotomy for abdominal aortic aneurysm repair. Br J Surg 2005;92:1208-11.

15. Lord RS, Crozier JA, Snell J, Meek AC. Transverse abdominal incisions compared with midline incisions for elective infrarenal aortic reconstruction: Predisposition to incisional hernia in patients with increased intraoperative blood loss. J Vasc Surg 1994;20:27-33.

16. Sørensen LT, Hemmingsen UB, Kirkeby LT, Kallehave F, Jørgensen LN. Smoking is a risk factor for incisional hernia. Arch Surg 2005;140:119-23.

17. Sanders DL, Kingsnorth AN. The modern management of incisional hernias. BMJ 2012;344:e2843.

18. Israelsson LA. Incisional hernias in patients with aortic aneurysmal disease: The importance of suture technique. Eur J Vasc Endovasc Surg 1999;17:133-5.

19. Altieri MS, Yang J, Jones T, Voronina A, Zhang M, Kokkosis A, et al. Incidence of ventral hernia repair after open abdominal aortic aneurysm and open aortofemoral or aortoiliac bypass surgery: An analysis of 17,594 patients in the State of New York. Am Surg 2018;84:1388-93.

20. Indrakusuma R, Jalalzadeh H, van der Meij JE, Balm R, Koelemay MJW. Prophylactic mesh reinforcement versus sutured closure to prevent incisional hernias after open abdominal aortic aneurysm repair via midline laparotomy: A systematic review and Meta-analysis. Eur J Vasc Endovasc Surg 2018;56:120-8.

21. Anderson DW, Edwards TK, Ricketts MH, Kuivaniemi H, Tromp G, Stolle CA, et al. Multiple defects in type III collagen synthesis are associated with the pathogenesis of abdominal aortic aneurysms. Ann N Y Acad Sci 1996;800:216-28.

22. Nishihara M, Aoki H, Ohno S, Furusho A, Hirakata S, Nishida $\mathrm{N}$, et al. The role of IL-6 in pathogenesis of abdominal aortic aneurysm in mice. PLoS One 2017;12:e0185923. 